\title{
Pesma Branka Radičevića Devojka na studencu u mađarskom prevodu
}

\author{
PÉTER MILOSEVITS \\ ELTE Szláv Tanszék, Budapest, Pf. 107, H-1364
}

\begin{abstract}
Girl at the well" - the first poem of the first book (1847) of Branko Radičević - pioneer of the Serbian romantic lyrical poesy - is the poetic overture of a new area. It is the prototype of the just starting popular (folksy) diskurs; sounds like a real folksong, but written by Branko Radičević.

The poem was translated - as the subtitle says "from the original Serbian" - by the Hungarian poet János Vajda at the end of his lifecarreer, in 1885. The translation has not succeeded well, it is very clumsy, in spite of the fact that Vajda was one of the greatest Hungarian poets.

Thesis and final conclusion of the study: at that time Vajda had been over on his popular style, and wrote mainly philosophical poems. In addition, the popular model was pushed into the background in the Hungarian poetry.

Keywords: literary translation, popular (folksy) style, literary trends and era
\end{abstract}

1. Poznatu pesmu Branka Radičevića Devojka na studencu na mađarski jezik je preveo velikan mađarske poezije Janoš Vajda (Vajda János, 1827-1897), pod naslovom: A leány a kútnál, „Radicsevics Sándortól. Szerb eredetiből.” 19. juli, 1885. U mađarskim antologijama srpske (i jugoslovenske) poezije i književnosti: Jugoszláv költők antológiája (Bp. 1963), A szerbhorvát irodalom kistükre (Bp. 1969). Vajdin prevod nije preštampan, a nije napravljen ni nov. Dobro je što Vajdin prevod nije preštampan, zato što je loš; ali je šteta što nije napravljen nov prevod, zato što je pesma važna.

Pesma Devojka na studencu stoji na istaknutom, simboličnom mestu istorije srpskog pesništva: kao prva pesma prve zbirke Branka Radičevića (Pesme, 1847), nalazi se bukvalno na čelu novije srpske lirike, začete u duhu Vukove reforme, bazirane na narodnom jeziku i poetskoj strukturi narodne poezije. Devojka na studencu je do te mere verna vukovskim narodnim načelima da je ona u stvari narodna pesma koju je napisao Branko Radičević; nije slučajno i ušla u narod koji je peva kao svoju (sa ponavljanjem stihova i napevom).

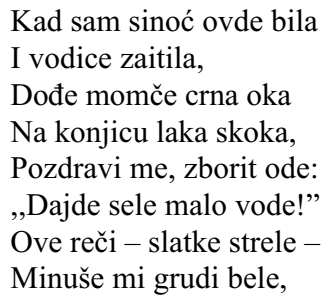




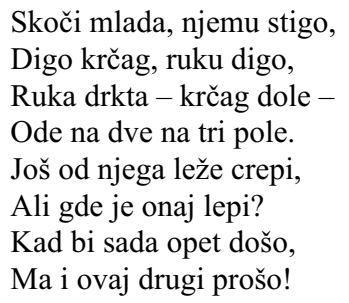

2. Janošu Vajdi nije pošlo za rukom da u prevodu napravi mađarsku narodnu pesmu:
1. Ahogy tegnap este itten
2. Egy kis vizet merítettem,
3. Fürge paripán elém
4. Fekete szemü legény
5. Szökken és beszélni kezd:
6. „Hugom, adj egy kis vizet!”
7. E szók, nyilak - édesek -
8. Átverték a szivemet.
9. Közeledem hirtelen,
10. Ah, de reszket a kezem.
11. A korsómat ejtem földre
12. Három négy darabra törve.
13. Még mind itt a sok cserép,
14. Hajh, de hol van ő, a szép?
15. Jönne bár most ide, hej,
16. Másik is hadd törne el...!

U prevodu ima generalnih i pojedinačnih, strukturalnih i jezičko-stilskih promašaja.

Pre svega nije jasno zašto se prevodilac umesto simetričnih osmeraca originala opredelio za sedmerce. Dalje: ako je već izabrao sedmerac, zašto ga nije ostvario dosledno? Naime, u 1-2. i 11-12. stihu ipak je zadržao osmerce. I najzad: zašto sedmerci nisu istovetni? U svega dvanaest stihova ima čak četiri različite vrste sedmeraca: $4+3,3+4,2+3+2$ i $3+2+2$.

Stalne promene ritma deluju kao falš pesma. Uloga ritma je pak toliko jaka da utiče i na rimovanje. Kada su rimovani stihovi ritmički neujednačeni, gubi se i jaka dvosložna rima (,Szökken és beszélni kezd: | Hugom, adj egy kis vizet”, $3+4 \mid 2+3+2$ ), dok ritmička harmonija pojačava i slabiju rimu (,Még mind itt a sok cserép, | Hajh, de hol van ö, a szép?", 4+3 | 4+3).

Stilski atentat na narodni duh poezije predstavljaju opkoračenja 3, 4. i 5. stiha sa rogobatnom predikatskom konstrukcijom, razbijenom radi rime:

$$
\begin{aligned}
& \text { Fürge paripán elém } \\
& \text { Fekete szemü legény } \\
& \text { Szökken és beszélni kezd }
\end{aligned}
$$

Sintagma „elém szökken” razdvojena je ne samo opkoračenjem nego i ubačenim stihom, što deluje kao parodija. 
Oblik iz govornog jezika ,itten” - umesto književnog ,itt” (ovde) - u prvom stihu, na prvi pogled, izgleda kao ,ruralizacija”, kao neki namerno istaknut narodski izraz. Međutim, u drugom stihu odmah se ispostavlja da je taj oblik upotrebljen samo zbog rime (,,itten - merítettem”). Umesto stilskog efekta: tehnička izveštačenost, $\mathrm{u}$ narodnoj poeziji nezamisliva.

Izveštačene su i inverzije, takođe napravljene zbog rime (,nyilak - édesek” umesto normalnog ,édes nyilak”). U mađarskom jeziku, gde nema gramatičkih rodova, rogobatna je sintagma „ö, a szép” pogotovo zato što lična zamenica „ő” (3. lice jednine) ne sadrži aspekt; kao da u srpskom tekstu umesto „Ali gde je onaj lepi?” stoji „Ali gde je on, lep?” Pasivna konstrukcija u stihovima „A korsómat ejtem földre | Három négy darabra törve" (Svoj krčag spustim na zemlju | Slomljen na tri-četir komada) bukvalno znači da se krčag prvo slomio u rukama devojke, zatim ga je ona bacila namerno na zemlju a ne, recimo, na krov; ovo zadnje proističe opet iz inverzije radi rime: umesto uobičajene fraze ,földre ejtem”, u obrnutom redosledu: „ejtem földre” naglašava se mesto na koje se krčag spušta.

Usklici - „,ah”, „hajh” i „,hej” - možda bi po nameri prevodioca trebalo da pojačavaju narodnu atmosferu, mada je jasno da imaju i funkciju ritmičkod dodatka. Međutim ,ah" i ,hajh” nisu narodne reči, nego salonske i literarne, karakteristične pre svega za sentimentalizam. A upotreba usklika u funkciji rime (,,ide, hej” - „törne el”), i to na kraju pesme, izraz je potpune previdalačko-pesničke nemoći.

3. Zašto jednom pesniku svetskog ranga nije pošlo za rukom da prevede ovu jednostavnu pesmu? Jasno: upravo zbog njene jednostavnosti; a da prirodna jednostavnost ove vrste poezije uopšte nije jednostavna i neozbiljan stvar, pokazuje baš i neuspeh Vajdinog prevoda.

Janoš Vajda (1827-1897) latio se prevođenja Brankove pesme u pogrešno vreme. U svojoj mladosti i on je pisao u narodnom stilu, pod snažnim uticajem Petefija, kasnije međutim napušta taj pravac koji tone u epigonizam, i od 1870-ih godina izgrađuje jedan kosmopolitski i vizuelno-filozofski pesnički model, sličan zreloj poeziji Silvija Strahimira Kranjčevića i nekim pesmama Laze Kostića. Prevodeći Devojku na studencu 1885. godine, Vajda je na vrhuncu tog novog i sopstvenog opredeljenja, čija je suština - prevazilaženje narodnog romantizma. Tom modelu više nije mogao da se vrati, čak ni radi jednog prevoda. 